\title{
The Possibilities of Dismantling the Racializing Strategies of White Supremacy
}

Critical Sociology 38(4) $611-618$ (C) The Author(s) 2012

Reprints and permission: sagepub.co.uk/journalsPermissions.nav DOI: $10.1 \mid 77 / 08969205$ | |43475| crs.sagepub.com (SAGE

\section{E. Lâle Demirtürk}

Bilkent University, Turkey

Melanie EL Bush, Everyday Forms of Whiteness: Understanding Race in a 'Post-Racial' World. Rowman and Littlefield: Lanham, MD, 2011; 330 pp.: 9780742599970 , \$85 (hbk), 9780742599987 , $\$ 34.95$ (pbk)In its challenge to traditional assumptions about many issues, Michael Hardt and Antonio Negri's Empire (2000) suggested that the political left had to be reconsidered in relation to 'a decentred configuration of empire that had many new, postmodern qualities'. Despite the controversial debate that this approach caused, both those on the right and those who were liberals began to recognize that the forces of globalization created 'a novel situation that required a new framework of analysis' (Harvey, 2005: 7). This also applies to the reconceptualization of white supremacy in an era of globalization that helps increase the gap between the rich and the poor caused by the logic of unequal structures. The fact that globalization does not just make the effort 'to homogenize the globe' but also 'to be a totality' leads Jean-Luc Nancy to observe that the West that has historically represented the universal and reason 'has come to encompass the world' in the ways in which it 'consolidates its power' (Bogues, 2010: 106).

The configurations of whiteness, seen as a discourse that maintains white privilege, have shifted in response to the impact of globalization. The white public imaginary has changed in line with the apparently dissolving boundaries around national identity, and normative conceptions of sexuality and gender. Several global sociopolitical changes have enabled reconfigurations of ethno-racial relations to form new modes of white privilege. The emergence of global divisions of labour, made possible by new global economic alliances, transnational migrant labour, and the rise of new technologies (to mention but a few causes) have helped transform national identities and production processes along with forms of governance and social relations across the globe. The tragedy of 9/11 reinforced the collective fear of the ethno-racial Other, developing strategies in the western nation states for self-protection, built upon technology-oriented surveillance. All of these changes have enabled the securitization of white privilege at the expense of Othering racial subjects. Hence, the 21 st century studies of whiteness speak back not only to these world-wide changes but also to the role of whiteness in 'securing privilege through seemingly neutral discourses' (Bhattacharyya et al., 2003: 10). However, these global forms of discourse do not stand alone. On the contrary, they depend on other discourses such as those of class and gender. 
A complex form of whiteness seems to rule the post-9/11 world in a way that conceals its racializing operations and underscores an ideology of whiteness that disempowers the racial Other. Given the intersections of whiteness with globalization in the late 20th and the early 21 st centuries, there is an increasing need to explore how whiteness is constituted both discursively and performatively in local spaces to enact specific functions such as 'acts of resistance, anti-racist whitenesses, "injured identities", immigrant variations of whiteness and destabilize whiteness as an enactment of privilege'. The demand for inquiry of whiteness in an era of globalization makes it possible to examine how 'transnational whiteness', and the international flow of people unravel the contradictory nature of 'tensions and intersections of whiteness as it goes global' (Steyn and Conway, 2010: 285). However, conversely enough, the global has become a local presence: the increasing gap between the rich and the poor has also assumed the racial markers of the white and the non-white in global cities such as New York, Los Angeles, and London. The contradictory discursive formations can best be studied in everyday performances of embodied whiteness in its local manifestations revealing the global underpinnings of white supremacy. The domain of white imaginary is never static, but fluid because it continues to respond to ever-changing sociocultural and political conditions.

Considering whiteness as a historical and social construct that represents it as a source of privilege, we can gain a deeper understanding of the impact of continued racism that can inform our effort to develop better strategies to end it. The white supremacist power regulates racialized bodies, and acts on them, because power operates 'in the constitution of the very materiality of the [racial] subject' (Butler, 1993: 34). Anti-black racism names a process of power that functions as a social discursive machine. As it is 'propagated through everyday life,' it guides our interactions invisibly and indirectly to the extent that 'it is embedded in our talk, in our assumptions, and in our everyday logics' (Warren, 1999: 756), escaping our awareness. A new understanding of how whiteness operates through the racialized disciplinary strategies and regulatory mechanisms in everyday encounters helps us become aware of how white power acts.

In The Wages of Whiteness (1991), David Roediger explores how the 'wages of whiteness' represent a privileged identity even for the members of the working class. He extends this argument in his 'Introduction' to his edited volume Black and White: Black Writers on What It Means to Be White (1998). Here he examines how a slave's viewpoint from the auction block can be taken as the lens through which African Americans think about and study whiteness - a critical lens to delve into the problematic of whiteness. Critical whiteness studies scholars often suggest that the real difficulty in studying whiteness lies at the heart of how it operates on the axis of 'invisibility' through institutional and discursive mechanisms. In White Women, Race Matters: The Social Construction of Whiteness (1993), Ruth Frankenberg links the dominance of whiteness to its normativity, masquerading as an effective form of power that determines social relations. The invisibility of whiteness is a direct result, in Richard Dyer's White (1997), of both its prescribed role as 'the norm, the ordinary, the standard' and its discriminatory practices to maintain its 'non-particular ... power' (Dyer, 1997: 3, 70). In his Black Bodies, White Gazes: The Continuing Significance of Race (2008), George Yancy finds the reason for this view in how whiteness acts as unmarked because it hides its racializing position of power through its presumed ahistorical location. Valerie Babb builds her book Whiteness Visible: The Meaning of Whiteness in American Literature and Culture (1998) on how the conceptualization of whiteness is shaped by an ideology that supports and maintains white privilege. Whiteness emerges in Theodore Allen's The Invention of the White Race: The Origin of Racial Oppression in AngloAmerica (1997), as a mere invention simply because it works as a 'system of social control' (Allen, 1997: 41), a view that Matthew Frye Jacobson identifies in Whiteness of a Different 
Color: European Immigrants and the Alchemy of Race (2002 [1998]) as the history of white supremacy as 'a history of power' (Jacobson, 2002 [1998]: 9).

Implying that the 'ownership' of whiteness is at the root of systemic racism, these scholars have paved the way for other scholars: for instance, George Lipsitz, in The Possessive Investment in Whiteness: How White People Profit from Identity Politics (2006 [1993]), believes American society, from slavery times on, has created 'a possessive investment in whiteness' (Lipsitz, 2006: 3), and Cheryl Harris, in 'Whiteness as property' (1998), defines whiteness as 'property' (Harris, 1998: 110) in legal terms. The fabricated dominance of white identity signifies the centrality of blackness to the construction of whiteness for Elizabeth Hale in Making Whiteness: The Culture of Segregation in the South, 1890-1940 (1998), because the social reality is defined, as Toni Morrison suggests in Playing in the Dark: Whiteness and the Literary Imagination (1993), in response to African Americanness as a tool for white cultural hegemony.

The strategies of normalization of whiteness are closely related to the racialization of blacks as the society in Eduardo Bonilla-Silva's view in Racism Without Racists: Color-Blind Racism and the Persistence of Racial Inequality in the United States (2006) is governed by the social relations that reinforce white privilege. Owing to its social constructedness, 'racial formation' is arbitrary for Michael Omi and Howard Winant in Racial Formation in the United States from the 1960s to the 1990s (1994). They claim that race 'has no fixed meaning' (Omi and Winant, 1994: 71). In this context, Howard Winant, in The New Politics of Race: Globalism, Difference, Justice (2004), suggests that there is a need to redefine the meaning of whiteness in such a way that 'it no longer has the power to impede class alliances' (Winant, 2004: 67). Gender and performance studies scholars, who build their research on Judith Butler's notion of gender identity as reiteration of a performative role in Gender Trouble: Feminism and the Subversion of Identity (1999 [1990]), argue that race and whiteness are constituted in the performances of individuals. Books such as Whiteness, Pedagogy, Performance: Dis/Placing Race (2007), edited by Leda M Cooks and Jennifer S Simpson, help us see how the whiteness of individuals themselves is embodied and relational in analysing the 'cultural practices of whiteness and racial identities as positioned and performative' (Cooks and Simpson, 2007: 3). Works in critical pedagogy studies also reveal how whiteness operates in diverse contexts, as Henry A Giroux's University in Chains (2007) explores, to transform the oppressive strategies of white supremacy into 'a discourse of critique and possibility' (Giroux, 2007: 6).

All of these works, not to mention an enormous amount of scholarship I have not been able to mention here, focus on the conceptualization of whiteness in its historical configuration and social ramifications to build an argument on its nature of historical and social constructions that produce a discursive frame through which the interpersonal relations are conducted. However, there have been only a few works that have focused on whites' own perspectives on the discursive practices of white supremacy in everyday life. Bridget Byrne's White Lives: The Interplay of 'Race, ' Class and Gender in Everyday Life (2006), Shelly Tochluk's Witnessing Whiteness: First Steps Toward an Antiracist Practice and Culture (2008), and Karyn D McKinney's Being White: Stories of Race and Racism (2005) are the only ones that reveal whites' perception of the everyday practices of whiteness in a well researched domain. These books inevitably bear the legacy of ideas that emerged from Henri Lefebvre, in the three volumes of Critique of Everyday Life (2008 [1947]). Translations of these volumes were published between 1991 and 2008 in America, and Lefebvre has demonstrated how he considers the study and critique of everyday life as pivotal to exposing the contradictions at the heart of any society. Similarly, in We Gotta Get Out of This Place (1992), Lawrence Grossberg takes issue with Lefebvre's critique, as he notes how the construction of everyday life reflects the contradictions in the society in terms of its investments in values, and who has access to the resources in social and cultural spaces. 
In this context, Melanie EL Bush's Everyday Forms of Whiteness is a major contribution to the field in unraveling the white mind-set behind the 'good intentions' of white people in their unconscious racialization of the non-whites. Previously published as Breaking the Code of Good Intentions (2004), this second edition includes recent opinion data and updated statistics in addition to Bush's interviews with white students and staff from Brooklyn College. The social and political change that has taken place in American society since she did her research for the original volume has found space in the book, because negative stereotyping of blacks expanded in the post9/11 period and during Obama's presidency, to include various groups ranging from Latino immigrants to people of Middle Eastern descent. In her preface, Bush explains that her main objective is to expose the operations of privilege and domination that go unseen because of the lack of white self-reflexive thinking.

This book, which has six chapters in addition to an Afterword and Epilogue, is Bush's attempt to examine the views of ordinary people on how various mechanisms of power reinforce narratives about race and support structural inequalities. In addition, she explores 'cracks in the wall of whiteness', by which she means 'potential opportunities' (p. 2) to disrupt those processes that generate white supremacy. She emphasizes that we need to become aware of the critical relationship between our everyday discursive personal and the institutional enactments which we need to discover in order to challenge structural hierarchies in the social systems. Hence, the book examines 'everyday processes and discourses of power, linking agency and structure within a political and economic framework' (p. 8). Even though Barack Obama's presidency has led white people to genuinely believe that we now live in a 'post-racial' American society, the everyday thinking comprises different mechanisms that lead white individuals to a lack of self-reflexivity about their unconscious racism. Since whites' attitudes are implicated in their acts, they need to critically examine the construction of their identities without falling into the fallacy that racism is an interpersonal problem rather than a system-wide pattern. In the four chapters following Chapter 1, which discusses the theoretical overview of critical whiteness studies, Bush's analyses of interviews makes it clear that institutional structures, which perpetuate racial inequalities, can be challenged by the 'everyday thinking' of ordinary people. She explores different aspects of whiteness, which influences perceptions about American society, reinforcing racialized thinking/acting in everyday life, through the perspectives of hundreds of young white participants in her research.

Chapter 2 focuses on racialized patterns of thinking among white students, whose understanding of what being white means is based on an assumption that the issue of race has nothing to do with them. They see 'race' as either a problem that makes it difficult to live as a white person or a problem that people of color have to tackle themselves. However, some students' views of the role of race in their lives define race as fluid, making it possible to develop a deeper understanding of the employment of race in the past and present as a pretext for domination; some white students express reluctance to socialize with non-whites, making 'justifying' remarks that they feel 'more comfortable with people they perceive to be like them' (p. 66). Even though white students distance themselves from the notion of race, they also express an awareness of how race functions in the media. The students also felt that certain types of policies on crime such as the 'war on drugs' are made more public with media representations of inner-city youth of color as mere drug addicts or dealers, whereas corporate crime and violence are never openly reported. There are prevalent contradictions among the white students regarding their views of non-whites. White students believe it is always non-whites who challenge the status quo and who blame the system for their personal deficiencies. For Bush, whites' resistance to talk about race and its impact on everyday experiences helps cover up structural inequalities, assuming the 
discursive frame of the culture of poverty, believing that people of color blame the system 'for their own personal deficiencies' (p. 92).

In Chapter 3, Bush analyses the respondents' claims about the meaning of American identity, because whites' assumptions about race help define who is entitled to citizenship. Bush sees numerous mechanisms including the pressure of economic downturns that reinforce the master narrative of race and nation. The narrative of whiteness enables white people to see hard work as the major factor in attaining the American dream rather than seeing through the ramifications of racism in everyday interactions. This is linked with the ambivalence in how what it means to be American and the entitlement to citizenship work in opposite ways: it creates a space for either reinforcing the structural inequalities or disrupting them. American identity is grounded in 'the democratic values, including idealized principles of freedom, justice, and individualism' (p. 104). How they are actualized in everyday life is closely related to what constitutes the American dream. Some whites believe that race is implicated in the notion of upward mobility because non-whites receive no institutional support whereas some others take the 'blame-the-victim' approach. One white female respondent believes that she lives through problems in financing her education because of the 'racially designated scholarships' (p. 115). The gap between the (privileged) whites and (subordinate) blacks seems to address the fact that whites' hard work pays off in the long run against blacks' failure due to their 'lack of effort' (p. 116). Most of these respondents target non-whites themselves, rather than blaming the racial inequities and hierarchies in the society at large.

Chapter 4 focuses on white students' interracial interactions and colorblindness, while getting feedback from their responses during interviews to the effect that from an early age their parents teach them about racial socialization. These sociocultural conditionings shape white-on-white socialization outside of campus, while their on-campus social interactions across the color line often maintain prejudices 'with awareness that they may be stereotypes' (p. 165). This upbringing is largely reflected in their views on education: there is a discrepancy between white students' views, which point to the need to diversify course materials, and non-white students, who far exceed white students in number, and who strongly claim the right to demand that diversity. Even though there are moments of awareness in white students about the non-whites' lived experiences of racism, they fail 'to develop a full understanding of the social dynamics that keep people separated' (p. 166).

Chapter 5 explores how race is understood in three areas of life: media, education, and the justice system. It examines the beliefs and attitudes about poverty and wealth as well as the underlying assumptions about race, seeking contexts in which whites question the dominant narratives about poverty and inequality. In terms similar to those in Chapter 3, the respondents believe that culturally weak groups blame the system for racial inequality, whereas the unmotivated individuals in these groups are accountable for their own personal failures. The reason for that is that whites believe that progress has already taken place in the society and if blacks get to earn advantages, then it means 'reverse discrimination to the exclusion and detriment of whites' (p. 200).

In Chapter 6, Bush suggests that white people use 14 mechanisms and locations through which they maintain racial inequality in the society. These mechanisms include such issues as the naturalization of poverty, wealth, and inequality, and that of whiteness, and the regulation of discourse in highlighting how everyday life is informed by racialized beliefs and narratives that ascribe superior status to whites and inferior status to non-whites. However, Bush also identifies nine 'cracks in the wall of whiteness' that can open up space for radical social change in challenging the historical inequalities that are rooted in American institutions and 'sustained by ideological narratives that support and justify racialized patterns' (p. 203). She suggests the term 'cracks in the wall of whiteness', because she also sees in many of these mechanisms 'the potential for challenging' rather than 
reinforcing the racialized structures of inequality. These cracks include ambiguities and contradictions in how the visibility of the power differential between whites and blacks provides a space for discussing the way race shapes different groups' lives differently; and confusion that exposes whites' uncertainty as to why they feel vulnerable in their social encounters with black people. Such cracks help white people interrogate and realize the fact that an unequal society is an unstable and unhealthy one 'even for those with privilege'.

Bush has added a separate sub-section to this second edition, under the heading of Increased Visibility and Higher Levels of Representation, to suggest that the increased visibility and representation of people of color such as the historical moment of Obama's presidency signifies hope for new possibilities for positive change. She is realistic enough to state that none of these 'cracks' provide the kind of change and transformation necessary 'in everyday consciousness' to subvert white supremacy. She strongly believes, however, that Americans now have a better chance for transformative impetus through 'understanding the mechanisms of reinforcement and the possibilities for change' (pp. 218-222). She claims that white supremacy is not only embedded in institutional structures, but also continues to shape everyday perceptions to the extent that patterns of racial inequality are maintained, while at the same time it is capable of producing social and political spaces to challenge them. She suggests that new intellectual strategies have to be developed 'to foster the social awareness needed to challenge the history of inequality and injustice in our society' (p. 239).

In the Afterword, Bush indicates that $9 / 11$ has made visible changes across the globe, not to mention the conservative political discourse that has suppressed inquiry, and an all-pervasive public debate on patriotism in American society. She sees a chance for the individuals who want to make a difference in developing alternative strategies to interpret social and political events that shape people's lives. In the Epilogue, Bush suggests that racial stereotypes serve as useful tools for the justification of why poverty exists, explaining it in terms of personal and cultural weaknesses. She takes a different look at Obama's presidency. The fact that Obama, like other people of color in high profile positions, may inadvertently support the fallacy that non-white people now have equal access to upward mobility. While she asserts that this way of thinking makes it difficult for whites to see and challenge the institutional patterns of inequality, she retains strong hope that 'cracks' will help open up spaces to disrupt the white supremacist capitalist system to create 'a world anew' (p. 256).

All in all, Bush examines how the current situation of racial discrimination takes on different forms through a variety of unconscious racist practices in everyday face-to-face interpersonal relations. Applying different discursive frames to interpret one's values, behaviour, and experiences in different terms of value than the racialized subject creates an effective strategy of maintaining racial difference against which white people define who they are. There is not just the power of institutions through whose subtle workings individuals are racialized and governed by the social stigmatization of their skin color, but also individuals expose an unconscious racism in which their attitudes to people of color become verbally or physically destructive. Deconstructing whites' selfperceptions and self-evaluations about what constitutes whiteness and its social signifiers such as privilege is, Bush admits, a hard task in exposing how white people contribute willingly to the perpetuation of a social, economic and political system that privileges white people on the basis of their color(lessness). The act of self-reflexivity prepares the ground for the whites' critical interrogation of the normative values that provide a racial hierarchy behind the so-called meritocracy and colorblindness in working with non-white citizens to bring about social change and transformation in restoring the democratic ideal. 
This highly compelling and thought-provoking book achieves this impossible task, and contributes significantly to scholarship not only on sociology, critical race studies, and related fields, but also on critical whiteness studies, which engage a variety of disciplines across academia. The book engages an ongoing dialogue with the current issues of race and racialization in contemporary American society, extending the discussion of larger implications of everyday 'doing race' to the global scene. Academically rigorous and theoretically sophisticated, Everyday Forms of Whiteness invites the reader to commend Professor Melanie EL Bush for her superb examination of the everyday thinking and practices of ordinary white people, while hoping for a social and political transformative change both in the USA and across the globe.

\section{References}

Allen TW (1997) The Invention of the White Race: The Origin of Racial Oppression in Anglo-America. London: Verso.

Babb V (1998) Whiteness Visible: The Meaning of Whiteness in American Literature and Culture. New York, NY: New York University Press.

Bhattacharyya G, Gabriel J and Small S (2003) Race and Power: Global Racism in the Twenty-First Century. New York, NY: Routledge.

Bogues A (2010) Empire of Liberty: Power, Desire, and Freedom. Hanover, NH: University Press of New England.

Bonilla-Silva E (2006) Racism Without Racists: Color-Blind Racism and the Persistence of Racial Inequality in the United States. Lanham, MD: Rowman and Littlefield.

Bush MEL (2004) Breaking the Code of Good Intentions: Everyday Forms of Whiteness. Lanham, MD: Rowman and Littlefield.

Butler J (1993) Bodies That Matter: On the Discursive Limits of 'Sex'. New York, NY: Routledge.

Butler J (1999 [1990]) Gender Trouble: Feminism and the Subversion of Identity. New York, NY: Routledge. Byrne B (2006) White Lives: The Interplay of 'Race', Class and Gender in Everyday Life. New York, NY: Routledge.

Cooks L and Simpson JS (2007) Introduction. In: Cooks LM and Simpson JS (eds) Whiteness, Pedagogy, Performance: Dis/placing Race. Lanham, MD: Rowman and Littlefield, 1-23.

Dyer R (1997) White. New York, NY: Routledge.

Frankenberg R (1993) White Women, Race Matters: The Social Construction of Whiteness. New York, NY: Routledge.

Giroux HA (2007) The University in Chains: Confronting the Military-Industrial-Academic Complex. Boulder, CO: Paradigm.

Grossberg L (1992) We Gotta Get Out of This Place: Popular Conservatism and Postmodern Culture. New York, NY: Routledge.

Hale GE (1998) Making Whiteness: The Culture of Segregation in the South, 1890-1940. New York, NY: Pantheon Books.

Hardt M and Negri A (2000) Empire. Cambridge, MA: Harvard University Press.

Harris C (1998) Whiteness as property. In: Roediger DR (ed.) Black on White: Black Writers on What It Means to Be White. New York, NY: Schocken, 103-118.

Harvey D (2005) The New Imperialism. Oxford: Oxford University Press.

Jacobson MF (2002 [1998]) Whiteness of a Different Color: European Immigrants and the Alchemy of Race. Cambridge, MA: Harvard University Press.

Lefebvre H (2008 [1947]) Critique of Everyday Life: From Modernity to Modernism (Towards a Metaphilosophy of Daily Life), Volume 1. Translated by G Elliott. London: Verso.

Lipsitz G (2006) The Possessive Investment in Whiteness: How White People Profit From Identity Politics. Philadelphia, PA: Temple University Press.

McKinney KD (2005) Being White: Stories of Race and Racism. New York, NY: Routledge.

Morrison T (1993) Playing in the Dark: Whiteness and the Literary Imagination. New York, NY: Picador. 
Omi M and Winant H (1994) Racial Formation in the United States from the 1960s to the 1990s. New York, NY: Routledge.

Roediger DR (1991) The Wages of Whiteness: Race and the Making of the American Working Class. London: Verso.

Roediger DR (1998) Introduction. In: Roediger DR (ed.) Black on White: Black Writers on What It Means to Be White. New York: Schocken, 3-26.

Steyn M and Conway D (2010) Intersecting whiteness, interdisciplinary debate. Ethnicities 10(3): 283-291.

Tochluk S (2008) Witnessing Whiteness: First Steps Toward an Antiracist Practice and Culture. Lanham, MD: Rowman and Littlefield.

Warren JH (1999) It really isn't about you: whiteness and the dangers of thinking you got it. In: Nakayama TK and Martin JM (eds) Whiteness: The Communication of Social Identity. Thousand Oaks, CA: Sage, $177-197$.

Winant H (2004) The New Politics of Race: Globalism, Difference, Justice. Minneapolis, MN: University of Minnesota Press.

Yancy G (2008) Black Bodies, White Gazes: The Continuing Significance of Race. Lanham, MD: Rowman and Littlefield. 